\title{
Л.М. Матлай
}

Інститут геологічних наук НАН України, Київ

E-mail: lidijamatlai@ukr.net

\section{Біостратиграфічна характеристика юрських відкладів Рівнинного Криму та Присивашшя}

Представлено академіком НАН Украйни П.Ф. Гожиком

Наведено біостратиграфічну характеристику юрських відкладів Рівнинного Криму та Присивашшя за молюсками, форамініферами, вапняковим нанопланктоном та спорами і пилком. Вперше визначено асоиіачіі вапнякового нанопланктону для нижнього байосу та апту свердловини Шубинська-7. Складено регіональну стратиграфічну схему юрсвких відкладів Рівнинного Криму та Присивашшя.

Ключові слова: юра, крейда, молюски, форамініфери, вапняковий нанопланктон, спорово-пилковий комплекс, Рівнинний Крим, Присивашшя.

Юрські відклади в Рівнинному Криму та Присивашші поширені в Північному, Центральному та Південному структурно-фаціальних районах [1]. Вони представлені нижнім та середнім відділами і лише на південному сході - верхнім. У Північному і Центральному структурно-фаціальних районах юрські породи складені пісковиками, аргілітами, алевролітами, з лінзами та прошарками вапняків, у Південному - пісковиками та конгломератами.

Відклади нижньої юри розкриті свердловинами в Північному Присивашші біля с. Новоолексіївка (свердловина Новоолексіївська Р-1), м. Генічеськ (свердловина Генічеська-5) та на півдні - поблизу смт Зуя (свердловина Зуйська-30), біля с. Шубине (свердловина Шубинська-7) (рис. 1). Вони представлені на півночі сірими алевролітами з прошарками глин та включеннями ефузивних порід, які на південь, у районі Зуї, фаціально заміщуються пісковиками [3]. Охарактеризовані амонітами верхнього тоару, форамініферами тоару та палінокомплексом тоару - аалену.

Середньоюрські відклади поширені на Новоселівському піднятті (свердловина Новоселівська Р-1), поблизу смт Зуя (свердловини Зуйська-9, 26, 30), м. Саки, біля с. Новоолексіївка (свердловина Новоолексіївська Р-1) та м. Генічеськ (свердловина Генічеська-5) (див. рис. 1). Вони представлені в Північному Присивашші темно-сірими брунатними глинами з прошарками пісковиків та конкреціями сидеритів, які на захід (у районі Новоселівського підняття) заміщуються ефузивно-осадовою товщею, що складена глинами, алевролітами, 3

(C) Л.М. Матлай, 2018 
малопотужними прошарками вапняків та ефузивів [3]. На півдні, в районі Зуї, свердловинами розкриті конгломерати, пісковики і глини, поширення яких на північ обмежено субширотним розломом [3]. Охарактеризовані молюсками бату, форамініферами байос-бату, палінокомплексом аалену.

Відклади верхньої юри відомі лише на південному сході Рівнинного Криму, де представлені рифогенними фаціями пізньотитонського віку. Охарактеризовані форамініферами верхнього титону, палінокомплексом титону, тинтинідами.

Найповніший розріз відкладів нижнього та середнього відділів юри розкритий свердловиною Новоолексіївська Р-1 (інтервал 2660,0-2789,0 м), що є стратотиповим розрізом атейської світи (див. рис. 1) [1]. За палеонтологічними рештками до складу атейської світи входять породи тоару - нижнього байосу.

Поблизу с. Новоолексіївка Генічеського району Запорізької області свердловиною P-1 розкрито:

2588,0 - 2660,0 м - пісковики світло-сірі, пухкі, не вапнисті, дрібно- і різнозернисті, зім'яті, з прожилками вуглисто-бітумінозних глин, місцями трапляється дрібнообкатана галька кварцу;

2660,0 - 2710,0 м - глини жовтувато-сірі, міцні, бітумінозні, окременілі, з тонкими лінзоподібними прошарками темно-сірого пісковику з галькою;

2710,0 - 2780,0 м - пісковики міцні, з прошарками темно-сірих міцних глин (інтервали 2720,0 м, 2740,0 м, 2760,0 м) та лінзами вапняків. В органогенно-уламковому вапняку (інтервал 2723,0-2729,0 м) спостерігаються членики голкошкірих, остракоди, гастроподи, форамініфери;

2780,0 м та нижче - конгломерати строкаті, окременілі, дуже міцні, складені зі слабо вапнистих уламків вивержених, метаморфічних та осадових порід.

Наявність конгломератів на Новоолексіївській площі розкрито свердловиною 6 в інтервалі 2664,0 - 2960,0 м. Конгломерати світло-брунатні і зеленуваті, з галькою вивержених порід і кременю, на гравійному цементі. Місцями конгломерати слабо метаморфізовані.

У відкладах стратотипового розрізу свердловини Р-1 в інтервалі 2754,0-2759,0 м у темно-сірих вапняках I.M. Ямниченком знайдені черепашки Pecten sp. та інші невизначені рештки двостулкових молюсків, а в інтервалі 2723,0-2729,5 м у чорному глинистому сланці - амоніт пізнього тоару Pseudogrammoceras fallacoisum (Bayle), а також Belemnites sp., Pseudomonotis sp. [4]. Байоські відклади розрізу свердловини охарактеризовані форамініферами Reinholdella media Kapt. (визначення О.К. Каптаренко-Черноусової), Lenticulina caucasica (Ant.), Spirillina involuta Ant. (визначення Д.М. П’яткової) [5].

За вапняковим нанопланктоном у глинах інтервалу 2735,0-2754,0 м автором встановлено шари з Lotharingius hauffii i Mitrolithus jansae раннього тоару [6] з комплексом характерних видів: Mitrolithus elegans Deflandre, M. jansae (Wiegand) Bown, Biscutum finchii Crux, Crepidolithus crassus (Defland re) Noël, Similiscutum cruciulus de Kaenel and Bergen, S. orbiculus de Kaenel and Bergen, Crucirhabdus primulus Prins and Rood, Schizosphaerella punctulata Deflandre and Dangeard, Lotharingius hauffii Grün and Zweili.

В аргілітах інтервалу 2721,0-2723,0 м виявлено комплекс вапнякового нанопланктону, що не заперечує пізньотоарський вік відкладів, визначений за макрофауною: Lotharingius hauffii Grün and Zweili, L. barozii Noël, L. sigillatus (Stradner) Prins, L. aff. velatus Bown 
Puc. 1. Схематична мапа докрейдової поверхні Рівнинного Криму та Присивашшя (за [2], із доповненням автора): 1 - докембрійські утворення; 2 - палеозой-верхньопротерозойські; 3 - пермо-тріасові; 4 верхньотріасові - нижньоюрські; 5 - нижньо- і середньоюрські (?); 6 - середньоюрські; 7 - середньо- і верхньоюрські (?); 8- верхньоюрські; 9 - ймовірні межі стратиграфічних комплексів; 10 - свердловини. Цифрами на мапі позначені свердловини: 1 - Новоолексіївська Р-1; 2 Генічеська-5; 3 - Красноперекопська-2; 4 - Березівська-4; 5 - Новоселівська Р-1; 6 - Миколаївська-1; 7 - Зуйська-9; 8 Зуйська-26; 9 - Зуйська-30; $10-$ Зуйська33;11-Шубинська-7;12-Журавкинська-1; 13 - Південно-Видненська-1

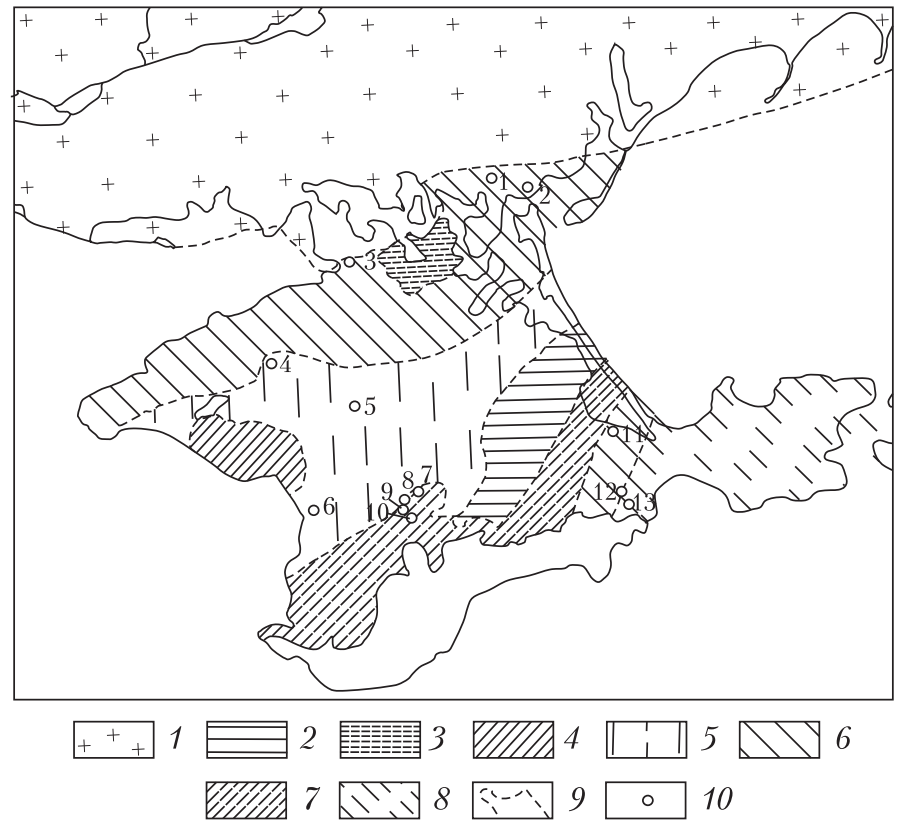

and Cooper, L. crucicentralis (Medd) Grün and Zweili, Tubirhabdus patulus Rood, Calyculus sp., Sollasites sp., Schizosphaerella punctulata Deflandre and Dangeard, Carinolithus superbus (Deflandre and Fert) Prins, Discorhabdus sp. та ін.

В глинистій товщі інтервалу вище за розрізом (інт. 2696,0-2702,0 м; 2659,0-2662,0 м; 2629,0-2636,0 м) цієї свердловини визначено Schizosphaerella punctulata Deflandre and Dangeard, Discorhabdus sp., Triscutum sullivanii de Kaenel et Bergen, Zeugrhabdotus erectus (Deflandre) Reinhardt, Watznaueria barnesae (Black) Perch-Nielsen, W.britannica (Stradner) Reinhardt, Retecapsa incompta Bown, Biscutum sp., B. dubium (Noël) Grün, Lotharingius hauffii Grün and Zweili. Перша поява виду Watznaueria britannica (Stradner) Reinhardt фіксується з нижнього байосу. За таксономічним складом комплекс належить нанопланктонній зоні NJ9 / Watznaueria britannica раннього байосу (за схемою П. Боуна, 1989) [7].

Аналогічні відклади в Присивашші розкриті свердловиною Генічеська-5 в інтервалі 2694,0-2910,0 м (парастратотиповий розріз атейської світи), що пробурена за 8 км на північний захід від м. Генічеськ Херсонської області (див. рис. 1):

2694,0-2876,0 м - аргіліти з тонкими прошарками алевролітів та дрібнозернистих пісковиків. В інтервалі 2842,0-2874,0 м зустрічаються масові скупчення уламків та відбитків фауни поганої збереженості. Пісковики (інтервал 2695,0-2699,0 м) cipi, темно-сірі, місцями чорні, олігоміктові, з глинистим і змішаним складом цементу. Алевроліти (інтервал 2751,02899,0 м) олігоміктові та кварцові, з глинистим і глинисто-кременистим цементом;

2876,0-2910,0 м - сірі пісковики та алевроліти з підпорядкованими прошарками аргілітів. Аргіліти темно-сірі і чорні, алевритисті, не вапнисті, з обвугленими рослинними рештками та глинисто-сидеритовими стяжіннями;

2910,0-3227,0 м - аргіліти з тонкими прошарками алевролітів, пісковиків і гравелітів. Аргіліти (2959,0-3223,0 м) сіро-зелені, переважно не вапнисті, з лінзами алевролітів та пісковиків, місцями сильно зім'яті та роздрібнені. Пісковики (інтервал 2937,0-3194,0 м) сіро- 
зелені, різнозернисті, поліміктові, з тонкими тріщинами, що заповнені кременистим цементом. Гравеліти (інтервал 3171,0-3175,0 м) зелені, дрібногравійні, складені з уламків ефузивів, філітів, кременистих порід, зеленувато-сірих пісковиків.

Л.М. Голубничою в аргілітах з глибини 2842,0-2846,0 м і 2853,0-2856,0 м визначено юрські форамініфери: Lenticulina perlucea Blank., L. ex gr. subinvoluta Kapt., L. sp. (aff. simplex), Reinholdella cf. incrassata (Kapt.), R. cf. media (Kapt.) [4]. За даними Г.О. Орлової-Турчиної у відкладах інтервалу 3219,0-3223,0 м виявлено палінокомплекс ранньолейасового віку. В породах інтервалу 3135,0-3194,0 м нею знайдено спори Osmunda jurassica K.- М., Equisetites rotundus (Naum.), Coniopteris sp. та пилок Pseudowalchia sp., Podocarpus arcusta K.-M., P. cf. nexilis Bolch., Paleoconiferus asuccata Bolch., що вказують на середньопізньолейасовий вік порід. У відкладах з інтервалу 2883,0-2884,0 м Г.О. Орлова-Турчина встановила палінокомплекс ааленського віку.

В аргілітах інтервалу 2694,0-2846,0 м Г.М. Волошиною визначено форамініфери Lenticulina sp., Reinholdella sp. і Г.О. Орловою-Турчиною - палінокомплекс байоського віку [8].

На жаль, відклади розрізу свердловини Генічеська-5 на вапняковий нанопланктон не досліджено.

У Великотокмацькому районі в товщі, розкритій свердловинами 1419, 1420, 1421, Д.М. П'ятковою виявлено комплекс форамініфер тоарського віку: Ammodiscus infimus Strick., Ammodiscus sp., Haplophragmoides sp., Trochammina squamataformis Kapt. [1].

На південно-східному Присивашші середньоюрські відклади атейської світи розкриті свердловиною Шубинська-7 (інтервал 4504,0-4550,0 м), що пробурена за 1 км на північний захід від с. Шубине Кіровського району в центроклінальній частині Індольського прогину (див. рис. 1). Вони представлені чорними аргілітами, з прошарками вапняків і пісковиків. Аргіліти (4509,0-4550,0 м) чорні, слюдисті, слабо алевритисті, з уламковим зломом, прошарками туфогенного матеріалу, міцні, місцями з дзеркалами ковзання. Трапляються включення розсипів піриту. Вапняки (4503,0-4509,0 м) темно-сірі, піщанисті, міцні. Пісковики (4509,0-4518,0 м) ясно-сірі, кварцові, поліміктові, дрібнозернисті, вапнисті, міцні, на глинисто-слюдисто-карбонатному цементі. В інтервалах 4518,0-4529,0 м і 4546,0-4550,0 м спостерігається темно-зелений глинистий сидерит, із зернами кварцу, прошарками кварцхлоритового і хлорито-слюдистого сланцю, лусками мусковіту [9].

В аргілітах Г.О. Орловою-Турчиною визначено спори Uvaesporites argenteoformis (Bolch.) Schul. і пилок Classopollis classoides (Pflug) Pococket Jons, а в пісковиках - пилок Coniferae, Picea singularae Bolch, Pinus sp. [8]. У сидериті інтервалу 4546,0-4550,0 м Л.М. Голубничою виявлено форамініфери роду Reinholdella, що характерні для відкладів аалену - байосу і поширені в байосі.

В аргілітах інтервалу 4546,0-4550,0 м автором встановлено комплекс вапнякового нанопланктону зони NJ9 / Watznaueria britannica раннього байосу: Watznaueria britannica (Stradner) Reinhardt, W. barnesae (Black) Bown, W. fossacincta (Black) Bown, W. manivitiae Bukry, Lotharingius crucicentralis (Medd) Grün and Zweili, L. sigillatus (Stradner) Prins, Lotharingius hauffii Grün and Zweili, L. barozii Noël, Biscutum dubium (Noël) Grün, Biscutum nozum (Goy) Bown, Zeugrhabdotus erectus (Deflandre) Reinhardt, Podorhabdus grassei Noël, Stephanolithion sp., Triscutum sullivanii de Kaenel et Bergen, T. tizienze de Kaenel et Bergen, T. beaminsterensis Dockerill. 
У сірих аргілітових глинах з обвугленими рослинними рештками та прошарками сірих кварцових дрібно- і середньозернистих пісковиків, розкритих свердловинами 062, 6к, 094, М.А. Вороновою зі співавт. виявлено палінокомплекс середньоюрського віку [1].

На південному заході Рівнинного Криму, в Альмінській западині, параметричною свердловиною Миколаївська-1 (с. Миколаївка Сакського району) розкриті нижньо-середньоюрські відклади в інтервалі 1145,0-3200,0 м, що представлені аргілітами, переверствованими алевролітами та пісковиками. Аргіліти (інтервал 1145,0-1635,0 м) темно-сірі до чорних, філітоподібні, тонкошаруваті, не вапнисті, зім’яті, місцями сидеритові, з прожилками кальциту. Алевроліти (інтервали 1200,0-1203,0 м, 1512,0-1516,0 м) темно-cipi, сірі, польовошпатокварцові. Пісковики (інтервал 1394,0-1398,0 м) сірі, польовошпато-кварцові, катаклазові. Проверстки чорних зім'ятих гравелітів спостерігаються з глибини 2626,0 м. Вони складені уламками метаморфізованих алевритових і глинистих порід, що зцементовані глинистим цементом, де зустрічаються вуглефіковані рослинні рештки. Численні тріщини з частими дзеркалами ковзання заповнені кварцом [10]. У породах інтервалу 1145,0-3200,0 м Г.В. Орловою-Турчиною визначено палінокомплекс тоар-ааленського віку: спори $S e$ laginella sp., Colamosporia sp., Equisetites sp., Osmunda sp., Coniopteris sp., ?Hausmannia sp., Dyctyophillidites sp., ? Pecopteris sp., Portinabulbifera Mal., Tripartina variabilis Mal., Trichomanes crassus (Naum.) Bolch., Camptotriletes sp. і пилок Cycas sp., Podocarpus aff. patula Bolch., Protopicea sp. $[9,10]$.

У Південному районі Рівнинного Криму відклади атейської світи розкрито свердловинами на Зуйській площі, що пробурені в підвищеній ділянці поблизу смт Зуя (див. рис. 1). Вони складені сірими алевролітами, дрібнозернистими пісковиками і темно-сірими до чорних аргілітами і глинами. Трапляються в верхній частині розрізу прошарки глинистого сланцю, строкатоколірні глини, місцями лінзи та прошарки галечнику і конгломератів. За даними Г.А. Орлової-Турчиної, що визначила спори та пилок з відкладів інтервалу 141,0223,0 м свердловини Зуйська-9, строкатоколірна товща належить до верхньої юри. M.I. Мандельштамом за комплексами остракод ці відклади віднесено до верхів титону низів крейди. Перекриваються гравійними пісковиками, слабозцементованими, з кутуватими уламками різних порід. Загальна потужність юрських відкладів понад 350 м.

Найбільш повний розріз атейської світи на Зуйській площі розкрито поблизу с. Верхні Орішники свердловиною 33 в інтервалі 467,0-590,4 м:

467,0-579,7 м - перешарування пісковиків та аргілітів. Пісковики темно-сірі поліміктові, дрібно-, середньо- і крупнозернисті, міцні, з кутастими зернами кварцу, включеннями сланцю, на карбонатно-глинистому цементі. Відмічаються прошарки чорних аргілітів. Аргіліти темно-сірі до чорних, міцні, слабо піщанисті, шаруваті, з прошарками сірого поліміктового пісковику. В інтервалах 423,1-488,5 м і 510,0-579,7 м трапляються включення дрібного гравію та кутастих уламків молочно-білого кварцу і кварциту. В інтервалі 555,0 555,8 м спостерігаються сліди брижі та хвилеприбійні знаки;

579,7-580,5 м - темно-сірі гравеліти, дуже міцні, на піщанисто-глинистому цементі. Уламковий матеріал представлений гравієм та напівкутастими уламками кварцу, окварцованих пісковиків і кварцитів;

580,5-590,4 м - темно-сірі пісковики, дрібнозернисті, поліміктові, щільно зцементовані. В інтервалі 584,0 - 586,0 м трапляється прошарок чорного міцного аргіліту. 
Нижня товща атейської світи, що датована за вапняковим нанопланктоном раннім тоаром, визначена в пісковиках та аргілітах інтервалу 478,2-508,5 м свердловини Зуйська-30 (рис. 2), що пробурена за 2,7 км на північний захід від свердловини 33. В них встановлено нанопланктонні шари з Lotharingius hauffii i Mitrolithus jansae [6, 11] з комплексом характерних видів: Lotharingius hauffii Grün and Zweili, Mitrolithus elegans Defland re, Crepidolithus pliensbachensis Crux, C. crassus (Deflandre) Noël, C. granulatus Bown. Вони незгідно перекриваються байоськими відкладами, охарактеризованими нанопланктоном. У пісковиках інтервалу 348,0-446,3 м свердловини Зуйська-30 і аргілітах інтервалу 271,7-279,0 м свердловини Зуйська-9 визначено комплекс вапнякового нанопланктону зони NJ9 / Watznaueria britannica раннього байосу [6,11]: Watznaueria britannica (Stradner) Rein hardt, W. barnesae (Black) Bown, W. fossacincta (Black) Bown, Triscutum sullivanii de Kaenel et Bergen, T. tizienze de Kaenel et Bergen, Lotharingius crucicentralis (Medd) Grün and Zweili, Crepidolithus crassus (Deflandre) Noël, Biscutum dorsetensis Varol and Girgis, B. dubium (Noël) Grün, Discorhabdus striatus Moshkovitz and Ehrlich.

В темно-сірих аргілітах інтервалу 451,0 - 542,0 м свердловини 33 I.М. Ямниченком визначено байоські молюски Meleagrinella sp., Witchellia sp.

Слід візначити, що в темно-сірих аргілітах інтервалу 266,3 м свердловини Зуйська-30 Д.М. П'ятковою виявлено форамініфери Glomospira sp., Lenticulina caucasica (Ant.), L. psebaica (Ant.), Reinholdella sp., Spirillina involuta Ant., що характерні, за їі висновками, для верхнього байосу, та I.M. Ямниченком - двостулкові молюски байосу-бату Posidonia buchi (Roem.) [1]. Але знахідки фауни встановлені у верхній піщано-глинистій товщі, що незгідно залягає на конгломератах з кутастими та обкатаними уламками зелених метаморфізованих сланців, зелених габро, габро-діориту, молочно-білого кварцу (інтервали 298,0305,4 м, 317,6-325,0 м, 329,1-349,4 м). Присутність відкладів верхнього байосу доведена комплексом молюсків зони Parkinsonia parkinsoni: Parkinsonia sp., Meleagrinella sp., Posidonia buchi (Roem.), Astarte sf. slavensis Ben., що визначені I.M. Ямниченком у темно-сірих аргілітах інтервалу 414,8-448,0 м свердловини 33. Це може свідчити про наявність на Зуйській площі інших літостратиграфічних горизонтів, що належать до верхнього байосу-бату. Зазначимо, що в цих відкладах трапляються уламки габро-діоритів, які спостерігаються на півночі, в баті, на Новоселівському піднятті.

Деякі дослідники [12] на Зуйській площі виділяють за літологічними ознаками утворення бітакської світи, порівнюючи їх зі стратотиповим розрізом поблизу м. Сімферополь в Гірському Криму. Але приймати конгломерати за маркуючий горизонт недоцільно, тим паче, що під час буріння їх виявляли як в юрських відкладах, так і в крейдових.

Відклади атейської світи в Рівнинному Криму та Присивашші незгідно залягають на тріасових і більш давніх утвореннях та перекриваються незгідно чайчинською товщею, або палеонтологічно охарактеризованими породами апту-раннього альбу, як зазначалося О.К. Каптаренко-Черноусовою на Новоолексіївській площі. Це добре простежується на прикладі розрізу свердловини Шубинська-7, де піщано-карбонатні утворення раннього апту незгідно залягають на теригенних породах раннього байосу (див. рис. 1, 3).

Підстеляючі відклади, які раніше були віднесені до пермо-тріасу, представлені дислокованими сіро-зеленими аргілітами, алевролітами, пісковиками, гравелітами та конгломератами, що змінені глибинним епігенезом та початковим метаморфізмом [2]. Про біль- 


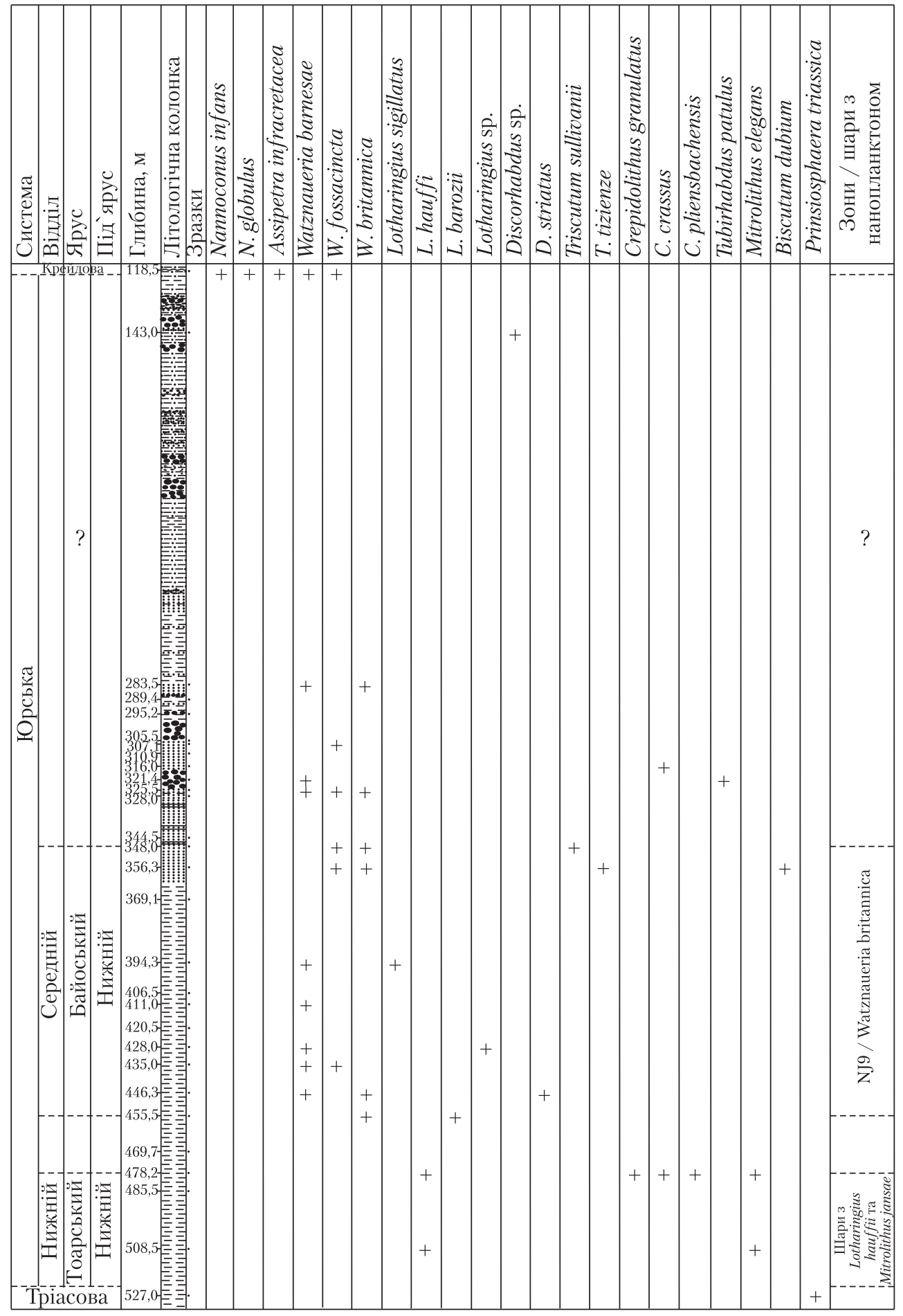

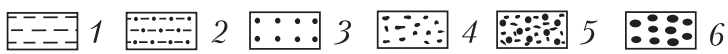

Puc. 2. Стратиграфічне поширення вапнякового нанопланктону у відкладах свердловини Зуйська-30. Умовні позначення: 1 - аргіліти; 2 - алевроліти; 3 - пісковики; 4 - гравеліти; 5 - гравеліти піщанисті; 6 конгломерати 
ший ступінь метаморфізму конгломератів згадано також у роботах Н.I. Черняк (1961 р.), М.А. Бородуліна (1962р.) та ін. Присутність в цих породах тріасових відкладів доведена знахідками фауни, спорово-пилковими комплексами та даними абсолютного датування порід [2]. У районі м. Саки та Євпаторії свердловинами 12 і 10 розкриті тріасові аргіліти та вапняки, що вміщують пелециподи карнію та палінокомплекси пізнього тріасу [2]. Наявність верхньотріасових відкладів на півдні дослідженої території підтверджено видами нанопланктону пізнього норію Prinsiosphaera triassica Jafar, що визначені автором у пісковиках глибини 527,0 м свердловини Зуйська-30 [11]. Місцями ця товща розмита, і юрські породи незгідно залягають на альбіт-хлоритових, кварц-кальцитових сланцях нижнього палеозою та мігматитах, гранітах, діоритах і габро-діабазах докембрію [10].

Чайчинська товща поширена в Північному і Центральному структурно-фаціальних районах Рівнинного Криму та Присивашшя [1]. Ї̈і вік (пізній байос-ранній бат) встановлений умовно за стратиграфічним положенням у розрізі та належності до пізньобайоськоїранньобатської спіліто-кератофірової формації. Типовим розрізом товщі є розріз свердловини Р-1 (інтервал 1570,0-1712,0 м), пробуреній поблизу с. Новоселівка на Новоселівському піднятті, за 35 км на північний схід від м. Євпаторія (див. рис. 1).

Свердловиною розкритий такий геологічний розріз:

1515,0-1580,0 м - у підошві пачки спостерігаються прошарки мікрокристалічного туфу та плагіоклазових порфіритів, вище залягають пісковики сірі і світло-сірі, кварцові, кварцглауконітові, вапнисті, переверствовані з алевролітами, конгломератами, вуглисто-глинистими сланцями з рідкими прошарками вапняків. У середній частині відмічено прошарки строкатоколірних утворень, а в покрівлі пачки - вивержені породи типу габро-діабазів;

1580,0-1624,0 м - вапняки сірі і темно-сірі, переверствовані з кременисто-глинистими і вуглисто-глинистими сланцями з рідкими прошарками кварцових пісковиків, у верхній частині трапляються прошарки строкатоколірних аргілітів і конгломератів;

1624,0-1760,0 м - мармуроподібні вапняки, з прошарками пісковиків та глинистих сланців, а також габро-діабазів і діабазів у середній частині пачки. В інтервалі 1665,01666,26 м виявлені темно-зелені діабази, з прожилками кальциту, рудними включеннями та дрібними ксенолітами осадових порід. Вони підстеляються світло-сірими вапняками, міцними, доломітизованими, мармуроподібними, з прожилками кальциту, що на контакті з виверженими породами перетворюються в білий мармур. В інтервалі 1639,0-1658,0 м розкриті габро-діабази темно-сірі, дрібно- і середньозернисті, піроксенові, складені звітрілим плагіоклазом типу лабрадору та піроксеном і рудними мінералами. Спостерігаються прошарки бурого баститу з численними зернами піриту, що заміщують піроксен.

Палеонтологічних решток у відкладах чайчинської товщі на сьогодні не визначено.

Чайчинська товща залягає незгідно на утвореннях атейської світи та перекривається без видимого перериву породами ішунської світи [5].

Ішунська світа поширена в Північному та частково Центральному структурно-фаціальному районах Рівнинного Криму та Присивашшя [1]. Її стратотиповим розрізом прийнято вважати розріз свердловини Новоселівська Р-1 в інтервалі 1387,0-1570,0 м, що розкрила такі відклади:

1370,0-1410,0 м - конгломерати, складені гальками темно-сірих вапняків, молочнобілого кварцу, кременю. Спостерігаються прошарки глинистих сланців та кварцових піско- 

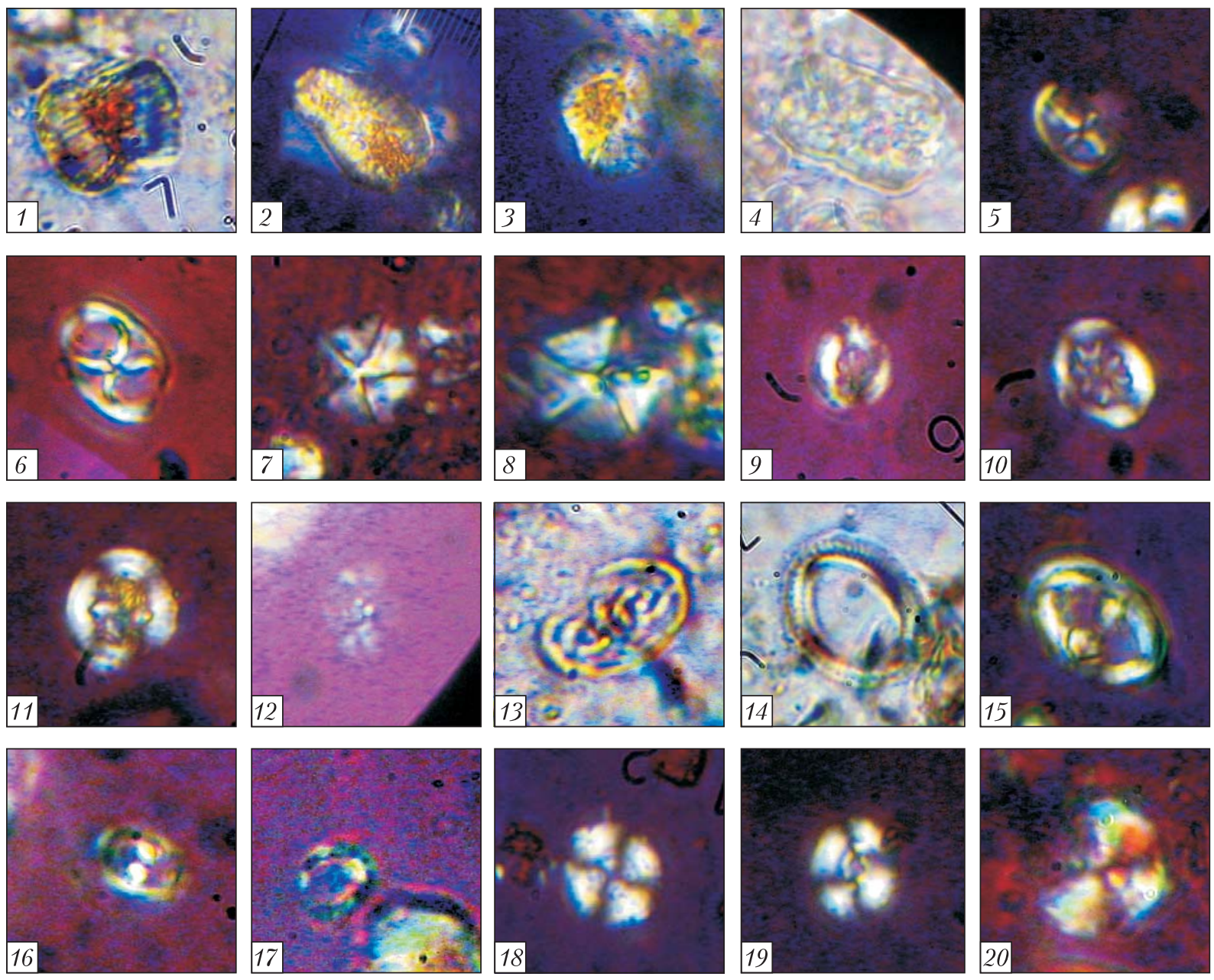

Puc. 3. Вапняковий нанопланктон із аптських відкладів свердловини Шубинська-7 (зображення в схрещених ніколях $90^{\circ}$, зб. 1575): 1 - Nannoconus truitti subsp. frequens Deres and Achéritéguy; 2 - Nannoconus kamptneri Bronnimann kamptneri; 3 - Nannoconus globulus subsp. globulus Bronnimann; 4 - Nannoconus dislocatus Perch-Nielsen; 5-Staurolithus aff. crux (Deflandre and Fert) Caratini; 6 - Tegumentum stradneri Thierstein; 7 - ? Micrantholithus obtusus Stradner; 8 - Micrantolithus hoschulzii (Reinhardt) Thierstein; 9 - Helenea chiastia Worsley; 10, 11 - Retecapsa angustiforata Black; 12 - Discorhabdus ignotus (Gorka) Perch-Nielsen; 13-? Rhagodiscusinfinitus(Worsley) Applegate; 14-Manivitellapemmatoidea(Deflandre) Thierstein; 15 - Zeugrhabdotus embergeri (Noël) Perch-Nielsen; 16 - Zeugrhabdotus erectus (Deflandre) Reinhardt; 17 - Rotelapillus laffitei (Noël) Noël; 18 - Watznaueria barnesae (Black) Perch-Nielsen; 19 - Watznaueria britannica (Stradner) Reinhardt; 20 - Watznaueria manivitiae Bukry

виків. Деякі дослідники цю пачку вважають базальним горизонтом нижньої крейди. Відмічено, що її перекривають строкатоколірні породи нижньої крейди, що в новоселівських свердловинах Р-7 і Р-9 підстеляються гравелітами та гравелітоподібними пісковиками ранньокрейдового віку;

1410,0-1515,0 м - глинисті та глинисто-вуглисті сланці, з прошарками кварцових i кварцово-польовошпатових пісковиків дрібнозернистих і грубозернистих, зцементованих кременисто-глинистим і залізисто-глинистим цементом. В інтервалі 1418,0-1422,0 м 
спостерігається прошарок зеленувато-сірого звітрілого плагіоклазового порфіриту. В середній частині пачки відмічено строкатоколірні алевроліти. Трапляються лінзи та прошарки габро-діабазів (інтервал 1504,0-1507,0 м) потужністю 4-5 м. Габро-діабази темносірі, середньозернисті, піроксенові, складені з плагіоклазу типу лабрадору, піроксену, рудних мінералів;

1515,0-1580,0 м - кварцові пісковики з прошарками алевролітів, конгломератів, глинистих сланців, габро-діабазів. На глибині 1517,0 м знайдена черепашка брахіоподи Terebratula aff. voghtii Moiss. поганої збереженості, що поширена переважно в юрських відкладах.

У цих породах I.M. Ямниченком визначено плечоногі та двостулкові молюски байосубату: Nucula ventricosa Pcel., Lucina bellona (Orb.), Terebratula aff. voghtii Moiss., a O.К. Каптаренко-Черноусовою - середньоюрські форамініфери Reinholdella media Kapt.

Вік світи, як середньо-пізньобатський, встановлено лише за поодинокими палеонтологічними рештками та стратиграфічним положенням у розрізі [5].

У Центральній частині Рівнинного Криму батські відклади виявлено в зразках керну свердловини Березівська-4 (інтервал 2438,0-2447,0 м), пробуреній на від’ємній структурі поблизу с. Березівка Роздольненського району Криму (див. рис. 1). Вони представлені міцними алевритами, не вапнистими, дрібношаруватими, що доверху заміщуються різнозернистими пісковиками, з включеннями гравію та прошарками алевриту та алевроліту. Пісковики червоно-бурі, місцями сірі, часто тріщинуваті, із дзеркалами ковзання. В них місцями трапляються рослинні рештки.

В алевритах цієї свердловини автором виявлено комплекс вапнякового нанопланктону, що складається з видів Watznaueria barnesae (Black) Perch-Nielsen, W. fossacincta (Black) Bown, Schizosphaerella punctulata Deflandre and Dangeard, Lotharingius sigillatus (Stradner) Prins, L. crucicentralis (Medd) Grün and Zweili, Staurolithites sp., Stephanolithion hexum Rood and Barnard, Ansulasphaera helvetica Grün and Zweili, Biscutum sp., Polypodorhabdus escaigii Noël, Pseudoconus enigma Bown and Cooper. За наявністю видів Ansulasphaera helvetica Grün and Zweili та Stephanolithion hexum Rood and Barnard вік відкладів від пізнього бату до раннього келовею.

У с. Красноперекопськ Красноперекопського району свердловиною 2 в інтервалі 3466,0-3472,0 м (див. рис. 1) розкрито середньоюрські відклади, які згодом автором за численним комплексом нанопланктону віднесено до пізнього бату.

Знизу до верху прослідковуються такі шари:

3466,0-3470,0 м - алеврити темно-сірі, слабо шаруваті, місцями озалізнені;

3470,0-3472,0 м - сланці темно-сірі, брудно-сірі;

3472,0-3525,0 м - сланці темно-сірі до чорного, міцні, слабо вапнисті, шаруваті, з прошарками темно-сірого вапняку, міцного, дрібнозернистого, з прожилками кальциту. В сланцях палеонтологічних решток не виявлено.

Комплекс вапнякового нанопланктону представлений видами Stephanolithion speciosum speciosum Deflandre, S. hexum Rood and Barnard, Retecapsa incompta Bown, Lotharingius contractus Bown and Cooper, L. crucicentralis (Medd) Grün and Zweili, L. sigillatus (Stradner) Prins, Schizosphaerella punctulata Deflandre and Dangeard, Tetrapodorhabdus shawensis Medd, Staurolithites sp., Zeugrhabdotus erectus (Deflandre) Reinhardt, Discorhabdus striatus Moshkovitz and Ehrlich, Podorhabdus grassei Noël, Watznaueria barnesae (Black) 


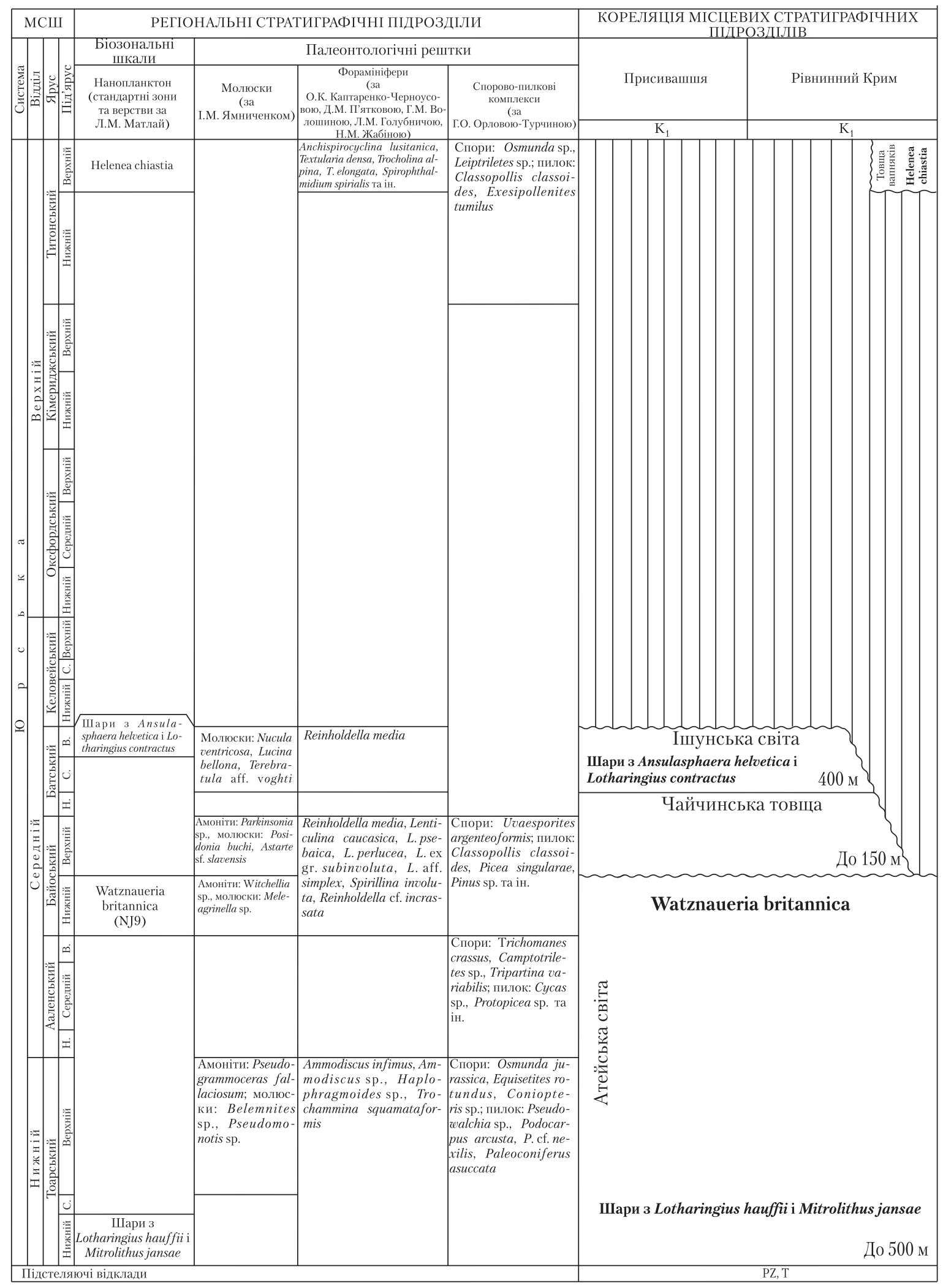

Puc. 4. Регіональна стратиграфічна схема юрських відкладів Рівнинного Криму та Присивашшя (складена автором за даними [3-6, 8-11]) 
Perch-Nielsen, W. fossacincta (Black) Bown, W. britannica (Stradner) Reinhardt, W.manivitiae Bukry. Одночасною наявністю видів Stephanolithion hexum Rood and Barnard та Tetrapodorhabdus shawensis Medd вік відкладів датовано пізнім батом (за схемою П. Боуна) [7].

Відклади ішунської світи залягають без видимого перериву на утвореннях чайчинської товщі та незгідно перекриваються породами нижньої крейди [5].

Верхньоюрські породи розкриті лише в південно-східній частині Рівнинного Криму свердловинами Видненська-1 (інтервал 2095,0-2500,0 м), Південно-Видненська-1 (інтервал 1604,0-2500,0 м), Журавкинська-1 (інтервал 2242,0-2500,0 м), Тамбовська-1 (інтервал 4073,0-4528,0 м) та ін. Вони представлені глинисто-карбонатними утвореннями кімериджу титону та рифогенними - титону. Глинисто-карбонатна товща складена темно-сірими до чорних пелітоморфними дрібнозернистими вапняками з прошарками мергелів. Н.М. Жабіною на різних рівнях товщі визначено форамініфери кімериджу і титону: Nautiloculina oolithica Mohl., Gaudryina jurassica Cush. et Glaz., G. vadaszi Cush. et Glas., Trocholina aff. aplina (Leup.), Epistomina aff. mosguensis Uhl., Quenqueloculina verbizhiensis Dulub та ін. [9]. Рифогенна товща представлена моховатко-водорослево-кораловими сірими вапняками 3 кремовим відтінком, місцями шоколадного, бурого і зеленувато-сірого відтінків. У відкладах свердловин Видненська-1, Південно-Видненська-1, Журавкинська-1 нею виявлено комплекс форамініфер титонського віку: Anchispirocyclina lusitanica (Egger), Textularia densa Hofman, Trocholina alpina (Leup.), T. elongata (Leup.), Pseudocyclammina ex gr. ragolai Cush. et Glaz., Bramcampella arabica Redm., тинтиніди Crassicollaria intermedia (D. Delga), Calpionella alpina Lorenz, Lorenziella transdanubica Knauer et Nagy, Tintinnopsella carpathica (Murgeanu et Filipescu), Calpionella oblonga (Cadisch) [9]. Але за останніми дослідженнями Н.М. Жабіної ці дві товщі треба відносити лише до верхнього титону [1].

У сірих алевритистих мергелях інтервалу 4269,0-4528,0 м свердловини Тамбовська-1 Г.М. Волошиною визначено титонські форамініфери Anchispirocyclina lusitanica (Egger), Spirophthalmidium spirialis Gorb., Trocholina elongata (Leup.), Haplophragmium sp., a Г.O. Opловою-Турчиною - спорово-пилковий комплекс титону: спори Osmunda sp., Leiptriletes sp. та пилок Classopollis classoides (Pflug) Pocock et Jons., Exesipollenites tumilus Balme [9].

Пізньотитонський комплекс вапнякового нанопланктону зони NJK / Helenea chiastia встановлено автором в темно-сірих мергелях інтервалу 2423,0-2433,0 м свердловини Журавкинська-1 та глинистих мергелях інтервалу 2418,0-2423,0 м свердловини ПівденноВидненська-1. Його складають види Polycostella beckmanii Thierstein, Helenea chiastia Wor sl ey, Hexalithus noeliae Loeblich and Tappan та ін. [11].

За результатами дослідження складена Регіональна стратиграфічна схема юрських відкладів Рівнинного Криму та Присивашшя (рис. 4), де біостратиграфічні підрозділи за вапняковим нанопланктоном прив'язані до МСШ.

Таким чином, у Рівнинному Криму та Присивашші за різними групами фауни та флори підтверджено наявність тоар-ранньобайоської атейської світи, пізньобайоських-ранньобатських відкладів чайчинської товщі, середньо- і пізньобатської ішунської світи та глинисто-карбонатних відкладів пізнього титону. На жаль, у більшості пробурених свердловин вихід керну 30-40 \%, тому прослідкувати фаціальний перехід між різними літо- і біостратиграфічними підрозділами в просторово-часовому відношенні на даний час неможливо. Але на сьогодні можна впевнено стверджувати про стратиграфічну неповноту юрського 
розрізу, що обмежується відкладами нижнього тоару, нижнього байосу, верхнього байосу, верхнього бату, верхнього титону.

Автор щиро вдячний канд. геол.-мін. наук В.А. Присяжнюку за щінні високопрофесійні консультащї під час написання чієї роботи.

\section{ЦИТОВАНА ЛІТЕРАТУРА}

1. Юрська система. Стратиграфія верхнього протерозою та фанерозою Украйни у двох томах. T. 1. Стратиграфія верхнъого протерозою, палеозою та мезозою України: Гожик П.Ф. (голов. ред.). Київ: ІГН НАН України, Логос, 2013. С. 431-497.

2. Денега Б.И. О возрасте и некоторых особенностях строения домеловых отложений Равнинного Крыма и Присивашья. Изв. АН СССР. Сер. геол. 1973. № 3. С. 11-121.

3. Стратиграфия, тектоника и нефтегазоносность Северного Кавказа и Крыма: Бурштар М.С. (ред.). Москва: Недра, 1969. 238 с.

4. Орлова-Турчина Г.А., Плахотный Л.Г., Савицына А.А. и др. О возрасте нижних горизонтов осадочного чехла Присивашья в районе Геническа и Ново-Алексеевки. Бюлл. МОИП. Отд. геол. 1968. № 5. С. $52-57$.

5. Астахова Т.В., Горак С.В., Краева Е.Я. и др. Геология шельфа УССР. Стратиграфия (шельф и побережье Чёрного моря). Киев: Наук. думка, 1984. 184 с.

6. Матлай Л. Биостратиграфическая характеристика юрских отложений Равнинного Крыма и Присивашья. Materialele conferinței ştiințifice naționale cu participare internaţională „Mediul şi deyvoltarea durabilă”. Ediția a III-a, consacrată aniversării a 80 ani de la naşterea prof. univ., dr. hab. Alexandru Lungu. 06-08 octombrie 2016. Chişinău, 2016. S. 37-43.

7. Bown P. Calcareous nannofossil biostratigraphy. London: Chapman and Hall, 1998. 318 p.

8. Волошина А.М., Орлова-Турчина Г.А. Литолого-стратиграфическая характеристика разрезов параметрических скважин Северного Причерноморья. Новые данные о геологическом строении и нефтегазоносности юга СССР по материалам региональных геолого-геофизических работ. Львов, 1973. С. 20 -49.

9. Лещух Р.Й., Пермяков В.В., Полухтович Б.М. Юрські відклади півдня України. Львів: Євросвіт, 1999. $336 \mathrm{c}$.

10. Волошина А.М., Денега Б.И., Орлова-Турчина Г.А. Результаты бурения параметрических скважин в Равнинном Крыму. Новые данные о геологическом строении и нефтегазоносности юга СССР по материалам региональных геолого-геофизических работ. Львов, 1973. С. 50-97.

11. Матлай Л. Вапняний нанопланктон з юрських відкладів Присивашшя та Рівнинного Криму. Палеонт. зб. 2012. № 44. С. 86-92.

12. Славин В.И., Чернов В.Г. Геологическое строение битакской свиты (тоар - средняя юра) в Крыму. Изв. ВУЗОВ. Геология и разведка. 1981. № 7. С. 21-33.

Надійшло до редакції 22.08.2017

\section{REFERENCES}

1. Jurassic system (2013). In Gottschick, P. F. (Ch. ed.). Stratigraphy of the Upper Proterozoic and Phanerozoic Ukraine in two volumes. T. 1. Stratigraphy of the Upper Proterozoic, Paleozoic and Mesozoic regions of Ukraine (pp. 431-497). Kiev: IGN NAS of Ukraine, Logos (in Ukrainian).

2. Denega, B. I. (1973). On the age and some features of the structure of the domelic deposits of the Flat Crimea and Prisivashija. Izvestiya AN SSSR. Ser. geol., No. 3, pp. 117-121 (in Russian).

3. Burstard, M. S. (Ed.). (1969). Stratigraphy, tectonics and oil and gas content of the North Caucasus and the Crimea. Moscow: Nedra (in Russian).

4. Orlova-Turchina, G. A., Plakhotny, L. G., Savitsina, A. A. et al. (1968). About the age of the lower horizons of the sedimentary cover of Prisivashija in the Genichesk and Novo-Alekseevka area. Byull. MOIP. Otd. geol., No. 5, pp. 52-57 (in Russian).

5. Astakhova, T. B., Gorak, S. V., Krayeva, E. Ya. et al. (1984). Geology of the shelf of the Ukrainian SSR. Stratigraphy (shelf and Black Sea coast). Kiev: Nauk. dumka (in Russian). 
6. Matlay, L. (2016, October). Biostratigraphic characteristics of the Jurassic sediments of the Flat Crimea and Prisivashija. Materials for participation in conferences, devoted to "Environment and sustainable development”. 3rd ed., dedicated to the 80th anniversary of the birth of Prof. Univ., Dr. hab. Alexandru Lungu (pp. 37-43), Kishinev (in Russian).

7. Bown, P. (1998). Calcareous Nannofossil Biostratigraphy. London: Chapman and Hall.

8. Voloshina, A. M. \& Orlova-Turchina, G. A. (1973). Lithological and stratigraphic characteristics of the cuts of parametric wells in the Northern Black Sea Region. New data on the geological structure and oil and gas potential of the south of the USSR based on materials from regional geological and geophysical works (pp. 20-49), Lviv (in Russian).

9. Leschukh, R. Ya., Permyakov, V. V. \& Polukhovich, B. M. (1999). Jurassic deposits of southern Ukraine. Lviv: Yevrosvit (in Ukrainian).

10. Voloshina, A. M., Denega, B. I. \& Orlova-Turchina, G. A. (1973). Results of Drilling Parametric Wells in the Plain Crimea. In New data on the geological structure and petroleum potential of the south of the USSR on the basis of regional geological and geophysical works (pp. 50-97), Lviv (in Russian).

11. Matlay, L. (2012). Calcareous nanoplankton from the Jurassic deposits of the Prisivashija and the Flat Crimea. Paleontol. zb., No. 44, pp. 86-92 (in Ukrainian).

12. Slavin, V. I. \& Chernov, V. G. (1981). Geological structure of the Bitak suite (Toarcian - Middle Jurassic) in the Crimea. Izv. VUZOV. Geologiya i razvedka, No. 7, pp. 21-33 (in Russian).

Received 22.08.2017

\section{Л.М. Матлай}

Институт геологических наук НАН Украины, Киев

E-mail: lidijamatlai@ukr.net

\section{БИОСТРАТИГРАФИЧЕСКАЯ ХАРАКТЕРИСТИКА ЮРСКИХ ОТЛОЖЕНИЙ РАВНИННОГО КРЫМА И ПРИСИВАШЬЯ}

Приведена биостратиграфическая характеристика юрских отложений Равнинного Крыма и Присивашья по моллюскам, фораминиферам, известковому нанопланктону и спорам и пыльце. Впервые определены ассоциации известкового нанопланктона нижнего байоса и апта скважины Шубинская-7. Составлена региональная стратиграфическая схема юрских отложений Равнинного Крыма и Присивашья.

Ключевые слова: юра, мел, моллюски, фораминиферы, известковый нанопланктон, споро-пыльцевой комплекс, Равнинный Крым, Присивашье.

\section{L.M. Matlaj \\ Institute of Geological Sciences of the NAS of Ukraine, Kiev \\ E-mail: lidijamatlai@ukr.net \\ BIOSTRATIGRAPHIC CHARACTERIZATION OF THE JURASSIC DEPOSITS OF THE FLAT CRIMEA AND THE NEAR-SIVASH REGION}

The biostratigraphic description of the Jurassic deposits of the Flat Crimea and the Near-Sivash region for mollusks, foraminifera, calcareous nannoplankton, spores, and pollen is given. For the first time, the associations of calcareous nannoplankton for the Lower Bajocian and Aptian wells of Shubinskaya-7 have been identified. The regional stratigraphic scheme of the Jurassic deposits of the Flat Crimea and the Prisivashija region is made.

Keywords: Jurassic, Cretaceous, mollusks, foraminifera, calcareous nannoplankton, spore-pollen complex, Flat Crimea, Near-Sivash region. 